\title{
Indicators of Food Security in Various Economies of World
}

\author{
Jolly Masih ${ }^{1}$, Amita Sharma ${ }^{1}$, Leena Patel $^{1} \&$ Shruthi Gade ${ }^{1}$ \\ ${ }^{1}$ Institute of Agribusiness Management, Swami Keshwanand Rajasthan Agriculture University, Bikaner, India \\ Correspondence: Jolly Masih, Institute of Agribusiness Management, Swami Keshwanand Rajasthan Agriculture \\ University, Bikaner 334006, India. Tel: 91-0151-225-2981. E-mail: jolly.iabm@gmail.com
}

Received: December 20, 2016

Accepted: January 31, 2017

Online Published: February 15, 2017

doi:10.5539/jas.v9n3p254

URL: http://dx.doi.org/10.5539/jas.v9n3p254

The research is financed by the first author of this article.

\begin{abstract}
Food security was a complex sustainable development issue, linked to health and nutrition. It was essential for sustainable economic development, environment, and trade. Many countries were facing food shortages and food distribution problems. This resulted in chronic and often widespread hunger in masses. All nations worldwide, including developed, developing and underdeveloped nations were taking initiatives at micro as well as at macro level to ensure food security. Food security was a complex condition and it had four dimensions - availability, access, utilization and stability. These dimensions were better understood when presented through a suite of indicators. The indicators of food security were analysed and it was found that climate change, government policies and interventions were the most challenging areas. The study was based on 150 research papers related to food security issue in underdeveloped, developing and developed nations. The research tried to embrace discussions related to food security across the globe into a single composition. The study has unveiled the important keywords related to indicators of food security like globalization, government policies and interventions, production technique, human development, PDS, hunger and poverty, hunger and malnutrition, farming technique, climate change, agriculture production, urbanization, health and human development, women empowerment, value chain policy, health and malnutrition etc. which would help policy makers to understand different issues related to policy making in a better way.
\end{abstract}

Keywords: food security, climate change, meta-analysis, sentiment analysis, agriculture, food

\section{Introduction}

Food security existed when all people, at all times, having physical and economic access to sufficient, safe and nutritious food to meet their dietary needs and food preferences for an active and healthy life (World Food Summit, 1996). Food security in future would be linked to our ability to adapt agricultural systems to extreme events. Extreme events, such as droughts and floods were forecasted to increase due to the climate change (Kumar \& Sharma, 2013). Ranging from overnight floods to gradually worsening droughts, these would have a range of impacts on the agricultural sector so as on the food security (Hossain, 2009). The sentiment analysis result showed that climate change across the globe was affecting all four dimensions of food security. Women empowerment, micro-credit and farming techniques were the enablers to food security and its dimensions (Khera, 2005). Precision was improved by making use of available secondary data through meta-analysis (Spieldoch, 2007). Few countries like Japan might even be able to export its rice, despite the prospects of a shrinking population and declining food consumption within the country. Exports (free trade) would provide Japan with excellent opportunities to manage agricultural land resources and ensure food security (Schanbacher, 2010). If countries were densely populated then grain consumption would climb up with rise in income, grain land area would shrink, and grain production might fall (Quisumbing, 2013). Achieving global food security whilst reconciling demands on the environment was the greatest challenge faced by mankind. By 2050 at least 9 billion people would need food, and increasing incomes and urbanization would inevitably lead to dietary change. The food security challenge would increasingly encompass the triple burden of malnutrition - under nutrition, obesity and micronutrient deficiencies (De Schutter, 2014). A convincing argument had been presented in support of the fact that advancements in biotechnology offer security and insurance protection for most potential threats to food security (Narayana, 2014). The study aimed to present the scenario of food security across the globe in 
compilation with sentiment analysis. In depth analysis of 150 research papers would help in analysing the situation about food security issues in world. Meta-analysis used a statistical approach for summarising the results of several studies into a single estimate. Developed, developing and underdeveloped countries had different issues in food security which were presented in this study along with the food indicators affecting them. Overall public sentiment was also shown in the study regarding major food policies and keywords related to food security.

\subsection{Objectives of the Study}

1) Identification of indicators of food security;

2) Identification and analysis of keywords in underdeveloped, developing and developed countries;

3) Sentiment analysis of keywords related to food security in underdeveloped, developing and developed countries;

4) Formulation of Trend Impressions Model with the identified keywords.

\section{Methodology}

\subsection{Area of Study}

Published research papers of developed, developing and underdeveloped countries on food security aspects were taken from the period of 2002-2015. Research papers were selected on basis of their contribution in aspects of food, agriculture and nutrition.

\subsection{Sources of Data}

The data required for accomplishment of objectives were collected through secondary data sources. Existing studies in the form of research papers, journal write-ups, essays, articles, and cases at national and international level, from EBSCO's database, Google Scholar, and government portals were collected to conduct this study.

\subsection{Sample Size}

150 articles were taken for study for the last 13 years i.e. from 2002-2015. 50 articles were taken from each economy i.e. developed, developing and underdeveloped economies, thus making a total of 150 articles. Articles were selected on different issues like food, nutrition, food availability and food security, economic and political conditions affecting food supply and value chain management in different economies.

\subsection{Research Tool}

Meta-analysis study had been done to achieve the objectives. It included sentiment analysis and trend impressions. Sentiment analysis was a type of natural language processing for tracking the mood of the public about a particular product or topic. Sentiment analysis, which was also called opinion mining, involved in building a system to collect and examine opinions about the product made in blog posts, comments, reviews or tweets.

Model of sentiment study named trend impressions would be used in which data would be divided in 4 zones (Masih, 2015).

1) Zone of trending in: Where upcoming and emerging trends would be analysed;

2) Zone of excellence: Trends which had already become popular and still had potential to gain more audience engagement were part of this zone;

3) Zone of all-time favourites - Trends which were evergreen and were stable in nature and occurrence;

4) Zone of fading out: Trends that faded with time after gaining popularity.

Popularity was measurement on the basis of selected keywords, viewership of data and number of days the trend was in use. Only those factors would be considered as trend which occurred upto $80 \%$ of total time span of data available. Following formulae would be used for each zone. A zone must fulfil both the criteria of time span and viewership.

1) Zone of Trending in:

$\frac{\text { Total time span (number of day) the trend occurred in data }}{100} \times 25$

$\frac{\text { Total viewership of trend occurred in data }}{100} \times 25$ 
* Viewership must increase with time.

2) Zone of Excellence:

Total time span (number of day) the trend occurred in data 100 $\times 50$

Total viewership of trend occurred in data

$100 \quad \times 50$

* All data lying between $>25-50 \%$ of time span \& viewership was a part of this model, data viewership must increase with time.

3) Zone of All Time Favourites:

$\frac{\text { Total time span (number of day) the trend occurred in data }}{100} \times 60$

$\frac{\text { Total viewership of trend occurred in data }}{100} \times 80$

* All data lying between $>50-80 \%$ of time span \& viewership was a part of this model, viewership must increase with time.

4) Zone of Fading out:

Total time span (number of day) the trend occurred in data 100 $\times 25$

Total viewership of trend occurred in data 100 $\times 25$

* Viewership must decrease with time.

\section{Results and Discussion}

\subsection{Objective 1: Identification of Indicators of Food Security}

The dimensions of food security were as follows: food availability, food access, utilization, stability. To fulfil this objective, standard indicators of food security were identified and listed from the FAO report (www.fao.org) and then the indicators were identified from 150 research papers and then these indicators were aligned as keywords according to the search intention. After that, the major influencing keywords in developed, underdeveloped and developing countries were identified and analysed statistically.

Identification of indicators of food security: Indicators were constructed from a set of observations or measurements, of food security-related conditions, which were classified according to a set of criteria, aggregated and placed in some program relevant perspective.

Table 1. Identification of indicators of food security

\begin{tabular}{ll}
\hline Indicator & Description \\
\hline Availability & $\begin{array}{l}\text { Average dietary energy supply adequacy; Average value of food production; Average protein supply; } \\
\text { Average supply of protein of animal origin; Share of dietary energy supply derived from cereals, roots } \\
\text { and tubers }\end{array}$ \\
& $\begin{array}{l}\text { Gross domestic product per capita (in purchasing power equivalent); Domestic food price index; } \\
\text { Access }\end{array}$ \\
Prevalence of food inadequacy; Share of food expenditure of the poor; Depth of the food deficit \\
Utilization & $\begin{array}{l}\text { Domestic food price volatility; Per capita food production variability; Per capita food supply variability; } \\
\text { Stability }\end{array}$ \\
& $\begin{array}{l}\text { Access to improved water sources; Percentage of adults who were underweight; Percentage of children } \\
\text { under } 5 \text { years of age whowere underweight; Prevalence of anaemia among pregnant women; Access to } \\
\text { improved sanitation facilities }\end{array}$ \\
\hline
\end{tabular}

As indicated above in Table 1, there were many commonly used measures that could reflect various dimensions of food security. In addition, there were usually a number of ways of measuring any single indicator. For example, an indicator defined as the "average total calorie consumption per capita" might be measured through a 
detailed dietary intake survey based on the weighing of food portions by survey enumerators, or from information based on a 24-hour recall of survey respondents. Similarly, measures of household income could be derived as a lump sum estimate based on the recall of a household head over the past month, or as an aggregate of income from individual household member activities based on individual recall. In some cases, there was international consensus on either measurement or analysis protocols for an indicator. In areas where women had traditionally not worked for wages outside the household, as in some where program capacity was limited, it might only be feasible to obtain consumption estimates based on respondent recall, rather than extensive food weighing methods.

\subsection{Objective 2: Identification and Analysis of Keywords in Underdeveloped, Developing and Developed Countries}

The extraction of keywords was done by thoroughly going through each individual research paper related to underdeveloped, developing and developed countries and help of tables was taken to analyse the keywords systematically. Keywords were those potential words which were used to reflect various scenarios of food security.

Table 2. Keywords identified in underdeveloped countries, developing and developed countries

\begin{tabular}{|c|c|c|}
\hline \multicolumn{3}{|c|}{ Underdeveloped Countries } \\
\hline Keywords & No. of related research & $\%$ \\
\hline Globalization & 2 & 4 \\
\hline Government policies \& interventions & 8 & 16 \\
\hline Production Technique & 5 & 10 \\
\hline Human development & 2 & 4 \\
\hline PDS & 2 & 4 \\
\hline Hunger \& poverty & 1 & 2 \\
\hline Hunger \& malnutrition & 4 & 8 \\
\hline Farming technique & 3 & 6 \\
\hline Climate change & 11 & 22 \\
\hline Agriculture production & 2 & 4 \\
\hline Urbanization & 2 & 4 \\
\hline Health \& human development & 2 & 4 \\
\hline Women empowerment & 2 & 4 \\
\hline Value chain & 2 & 4 \\
\hline Policy, Health \& human development & 2 & 4 \\
\hline Health & 0 & 0 \\
\hline Malnutrition & 0 & 0 \\
\hline Trade & 0 & 0 \\
\hline Total & 50 & $100 \%$ \\
\hline \multicolumn{3}{|c|}{ Developing Countries } \\
\hline Keywords & No. of related research & $\%$ \\
\hline Globalization & 2 & 4 \\
\hline Government policies \& interventions & 18 & 36 \\
\hline Production Technique & 1 & 2 \\
\hline Human development & 1 & 2 \\
\hline PDS & 1 & 2 \\
\hline Hunger \& poverty & 1 & 2 \\
\hline Hunger \& malnutrition & 4 & 8 \\
\hline Farming technique & 3 & 6 \\
\hline Climate change & 7 & 14 \\
\hline Agriculture production & 2 & 4 \\
\hline Urbanization & 2 & 4 \\
\hline Health \& human development & 2 & 4 \\
\hline
\end{tabular}




\begin{tabular}{|c|c|c|}
\hline Women empowerment & 0 & 0 \\
\hline Value chain & 2 & 4 \\
\hline Policy, Health \& human development & 2 & 4 \\
\hline Health & 1 & 2 \\
\hline Malnutrition & 2 & 4 \\
\hline Trade & 0 & 0 \\
\hline Total & 50 & $100 \%$ \\
\hline \multicolumn{3}{|c|}{ Developed Countries } \\
\hline Keywords & No. of related research & $\%$ \\
\hline Globalization & 2 & 4 \\
\hline Government policies \& interventions & 16 & 32 \\
\hline Production Technique & 5 & 10 \\
\hline Human development & 2 & 4 \\
\hline PDS & 2 & 4 \\
\hline Hunger \& poverty & 0 & 0 \\
\hline Hunger \& malnutrition & 0 & 0 \\
\hline Farming technique & 3 & 6 \\
\hline Climate change & 4 & 8 \\
\hline Agriculture production & 1 & 2 \\
\hline Urbanization & 1 & 2 \\
\hline Health \& human development & 1 & 2 \\
\hline Women empowerment & 0 & 0 \\
\hline Value chain & 0 & 0 \\
\hline Policy, Health \& human development & 0 & 0 \\
\hline Health & 0 & 0 \\
\hline Malnutrition & 0 & 0 \\
\hline Trade & 13 & 26 \\
\hline Total & 50 & $100 \%$ \\
\hline
\end{tabular}

Table 2 indicated that in underdeveloped countries climate change (22\%), government policies $(16 \%)$ and production technique $(10 \%)$ were the most discussed topics. In developing countries: government policies and interventions $(36 \%)$, climate change $(14 \%)$ and hunger and malnutrition $(8 \%)$ were the most popular. In developed countries: government policies and interventions (32\%), trade $(26 \%)$ and climate change $(8 \%)$ were discussed.

Table 3. List of similar keywords identified among underdeveloped, developing and developed nations

\begin{tabular}{lll}
\hline Underdeveloped Countries & Developing countries & Developed countries \\
\hline Climate change (22\%) & Climate change (14\%) & Climate change (8\%) \\
Govt. Policy and interventions (16\%) & Govt. Policy and interventions (36\%) & Govt. Policy and interventions (32\%) \\
Value chain (2\%) & Value chain (2\%) & \\
\hline
\end{tabular}

Table 3 indicated that climate change and government policies and interventions were the most burning topics related to food security in all the underdeveloped, developing and developed nations. While, value chain was also the matter of concern for underdeveloped and developing nations. 


\subsection{Objective 3: Sentiment Analysis of Keywords in Underdeveloped, Developing and Developed Countries}

Table 4. Major indicators influencing sentiments

\begin{tabular}{|c|c|c|c|}
\hline Keyareas & Underdeveloped Countries & Developing Countries & Developed Countries \\
\hline$\underline{\text { Positive Sentiment }}$ & $\begin{array}{l}\text { Govt. Policies, Women } \\
\text { Empowerment, Micro Credit }\end{array}$ & $\begin{array}{l}\text { Climate Change, Farming technique, } \\
\text { Govt. policies \& interventions }\end{array}$ & $\begin{array}{l}\text { Govt. Interventions, Farming } \\
\text { technique }\end{array}$ \\
\hline$\underline{\text { Neutral Sentiment }}$ & $\begin{array}{l}\text { Climate change, Agriculture } \\
\text { Production, Production Technique }\end{array}$ & Govt. Policies \& Interventions & Govt. Interventions \\
\hline$\underline{\text { Negative Sentiment }}$ & Climate Change & Govt. Policies \& Interventions & $\begin{array}{l}\text { Climate Change, Govt. } \\
\text { Interventions, Natural Disaster }\end{array}$ \\
\hline
\end{tabular}

Table 4 showed the indicators which were having maximum impact on the evaluation of research paper and simultaneously influenced sentiments of the researchers. In sentiment analysis, three sentiments were majorly identified. First sentiment was positive sentiment, which talked about those keywords which made positive and successful changes in food security. e.g. in underdeveloped countries, government policies were making positive impact to attain food security. Government was also focusing on women empowerment ad micro credit facilities to fight hunger and to ensure food security in underdeveloped countries, while in developing countries climate change, farming technique and government policies and interventions took the lead, on other hand, in developed nations, government interventions, trade and farming techniques were the influencing factors.

Second category of sentiment was neutral sentiment, where the reactions of people were neither good nor bad but still they were important. In underdeveloped countries climate change, agriculture production and production technique had neutral influence but in developing and developed nations, few government policies were taken as neutral, since they were log term in nature and their impact was still not known.

Third category of sentiment was negative, where people thought that significant work was not done in those areas and they require improvement. In few underdeveloped countries of Africa, climate change was completely avoided, in few developing countries like India, China and Pakistan, government policies at regional level were not very effective and required improvement,, in developed nations like USA, Canada and Australia climate change was a major challenge and people were not satisfied by the ways government tacked the issues of climate change and natural disasters.

\subsection{Objective 4: Formulation of Trend Impression Model with the Identified Keywords}

"Trend Impressions", this model studies the movement of keywords for each parameter e.g. Keywords in this case in 4 zones:

1) Zone of Popping in: Here those keywords (along with their numbers or percentage in research) were written which had emerged recently and were likely to get good response in future.

2) Zone of Excellence: This zone dealt with keywords having highest popularity. Keywords which draw high attention of readers, these keywords could be new or old.

3) Zone of Popping out: This zone would tell about keywords which initially had high audience/readers' attention but they faded with time, i.e., their readability and importance degraded quickly.

4) Zone of All Time Favourite: This was the zone of keywords performing consistently well over decided time frame. They were more stable in nature and did not easily fade with time. In this research, mapping of keywords had been done which include last 13 years i.e. 2002-2015. 


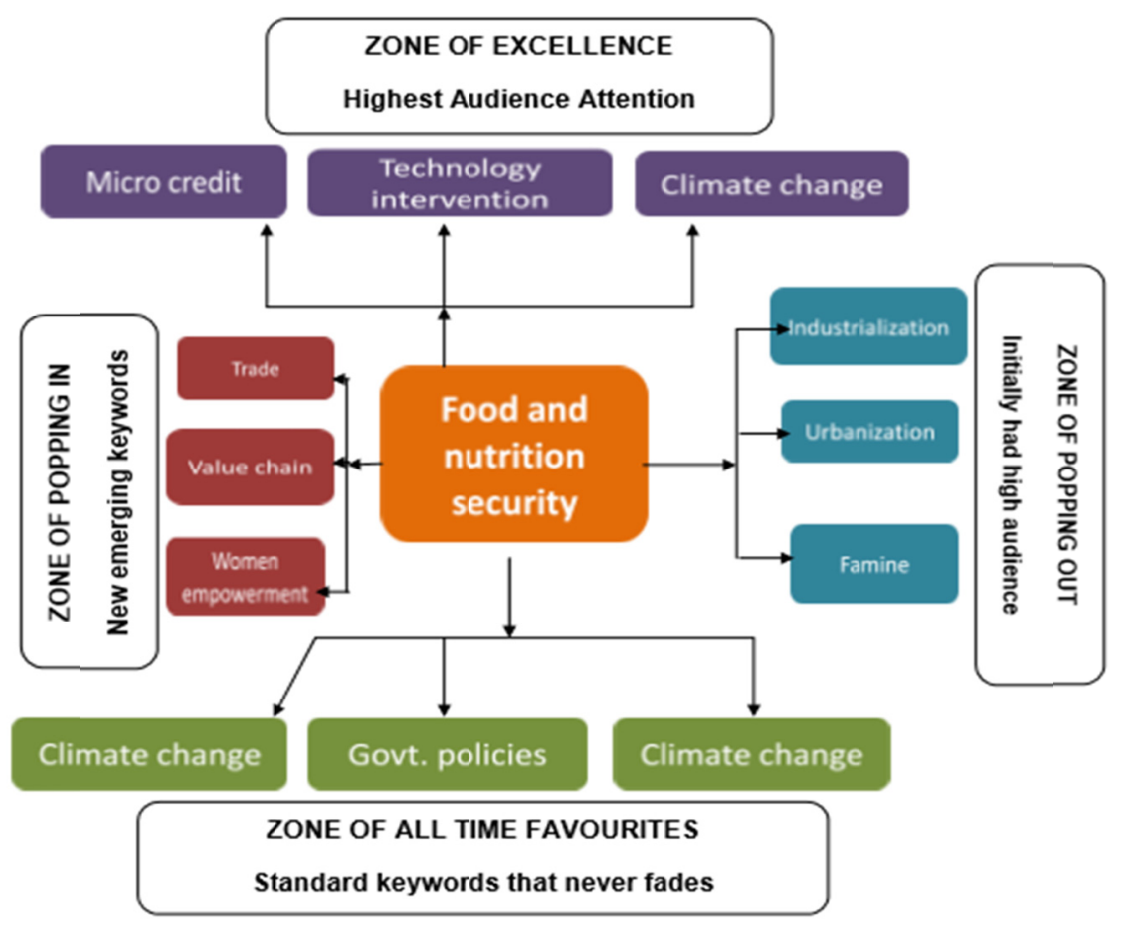

Figure 1. Model of trend impressions

Table 5. Keyword mapping using Trend Impressions Model for each KPI

\begin{tabular}{|c|c|c|}
\hline Developed countries & Developing Countries & Underdeveloped countries \\
\hline \multicolumn{3}{|l|}{ Zone of popping in } \\
\hline Trade, $20 \%$ Trade Agreements, $10 \%$ & Value chain, $2 \%$ Globalization, $2 \%$ & Value chain, $6 \%$ Women empowerment, $4 \%$ \\
\hline \multicolumn{3}{|l|}{ Zone of excellence } \\
\hline Technology interventions, $4 \%$ & Climate Change, $14 \%$ Farming Technique, $6 \%$ & $\begin{array}{l}\text { Microcredit, } 4 \% \text { Technology transfer, } 2 \% \\
\text { Climate change, } 6 \%\end{array}$ \\
\hline \multicolumn{3}{|l|}{ Zone of popping out } \\
\hline Food and health issues, $2 \%$ & Agriculture production, $4 \%$ Urbanization, $4 \%$ & $\begin{array}{l}\text { Agriculture Production, } 4 \% \text {, Access to } \\
\text { livelihood, } 2 \%\end{array}$ \\
\hline \multicolumn{3}{|l|}{ Zone of all time favourite } \\
\hline Climate change, $8 \%$ & $\begin{array}{l}\text { Government policies and interventions, } 36 \% \text {, } \\
\text { PDS, } 10 \% \text { Hunger and malnutrition, } 12 \%\end{array}$ & $\begin{array}{l}\text { Production technique, } 20 \% \text { Household food } \\
\text { security, } 8 \%\end{array}$ \\
\hline
\end{tabular}

Table 5 indicated that trade and trade agreements were the keywords that emerged recently and were likely to get good response in future because in a developed country like Japan where two third of the food security was ensured via trade as it was an import oriented economy. Likely in developing countries, globalisation has brought up a revolutionary change in growth of economy thereby ensuring the food security. Value chain management also gained good momentum in many countries and was likely to get a good response in future because the government in these countries were involved in storing, processing, transfer of technology, training, research and development etc. which would ultimately result in ensuring food security of a nation. Similarly, women-empowerment in underdeveloped countries like Bangladesh was playing a vital role in ensuring food security where formation of SHG's and involvement of women in these microfinancing institutions was in the path of progress and was recognised world-wide.

\section{Conclusion}

The study indicated that climate change, government policies and interventions were the most on-going trends discussed in the research papers that were taken under consideration. Climate Change influenced the agriculture production patterns in all underdeveloped, developing and developed nations which influenced the livelihood access as well. The major impact of livelihood access was seen in the underdeveloped countries which were 
economically very weak and in developed countries where natural disasters were occuring due to influence of climate change thus threatening the food security. On the other hand, government policies and interventions were most discussed topics in developing in developed countries. In developing country like India, National food security act which was the ongoing issue had gain more influential effect amongst the researchers, public distribution system and access to food through different food programmes were discussed in concerning underdeveloped nations and in developed nations the policies were like millennium development goals and global partnerships framed to ensure food security. Regarding sentiment analysis, it had been observed that, climate change was the major indicator influencing negatively as it affected all four dimensions of food security in all the underdeveloped, developing and developed nations while Women empowerment, micro-credit, farming techniques were on the positive side as these were becoming recently tapped areas to ensure food security. Also trade agreements, value chain management, globalization, women upliftment were among the recently developing trends on which most of the researches were done.

\section{References}

Achyut, D. (2005). Food Security and Tribal Livelihoods: Efforts in Remote Tribal Regions in Food Security System in India (p. 154). Concept Publishing Company, New Delhi.

Adamo, S. B. (2011). Slow-onset hazards and population displacement in the context of climate change.

Aggarwal, P. K., \& Sivakumar, M. V. K. (2011). Global climate change and food security in South Asia: An adaptation and mitigation framework. In L. Rattan, V. K. Sivakumar, S. M. A. Faiz, A. H. M. Rahman, I. Mustafizur, \& R. Khandakar (Eds.), Climate change and food security in South Asia (pp. 253-275). New York: Springer.

Ahmad, J., Alam, D., \& Hadsen, S. (2010). Impact of Climate Change on Agriculture \& Food Security in India (pp. 131-136).

Ahmad, J., Alam, D., \& Hadsen, S. (2011). Impact of climate change on agriculture and food security in India. International Journal of Agricultural Environmental and Biotechnology, 4(2), 129-137.

Brahmanand, P. S., Mohanty, R. K., \& Kumar, A. (2006). Integrated rice-fish farming (p. 78). Directorate of Water Management, Indian Council of Agricultural Research, Bhubaneswar.

Bundy, D., Burbano, C., Grosh, M., Gelli, A., Jukes, M., \& Drake, L. (2009). Rethinking School Feeding: Social Safety Nets, Child Development, and the Education Sector. Washington, D.C.: World Bank-WFP. https://doi.org/10.1596/978-0-8213-7974-5

Chaterjee, B. K. (2012). The National Food Security Bill, 2011: Right to entitlement to food and Nutrition (pp. 1-6). CUTS International.

De Schutter, O. (2014). Final report on the transformative potential of the right to food (A/HRC/25/5). 25th Session of the U.N. Human Rights Council, March 10, 2014. In O. De Schutter, \& K. Y. Cordes (Eds.), Accounting for Hunger: The Right to Food in the Era of Globalisation. Oxford, UK: Hart Publishing.

Drèze, J. (2004). Democracy and the Right to Food. Economic \& Political Weekly (April 24, 2004, pp. 1723-1731).

Duncan, J., \& Barling, D. (2012). Renewal through Participation in Global Food Security Governance: Implementing the International Food Security and Nutrition Civil Society Mechanism to the Committee on World Food Security. International Journal of Sociology of Agriculture and Food, 19(2), 143-161.

Edelman, M., Weis, T., Baviskar, A., Borras, S. M., Holt-Gimenez, E., Kandiyoti, D., \& Wolford, W. (2014). Introduction: critical perspectives on food sovereignty. The Journal of Peasant Studies, 41(6), 911-931. https://doi.org/10.1080/03066150.2014.963568

Friedmann, H., \& McMichael, P. (1989). Agriculture and the state system: The rise and fall of national agricultures, 1870 to the present. Sociologia Ruralis, 29(2), 93-117. https://doi.org/10.1111/ j.1467-9523.1989.tb00360.x

FSHB (Food Security in Haor Basin). (2012). Proceedings of the seminar on food security in Haor Basin, Shahjalal University of Science and Technology, October 15, 2012.

Ganesh-Kumar, A., Gulati, A., \& Cummings, R. Jr. (2007). Food grains Policy and Management in India Responding to Today's Challenges and Opportunities. International Food Policy Research Institute, Washington, DC. 
Gentilini, U., \& Webb, P. (2008). Howwere we Doing on Poverty and Hunger Reduction? Food Policy, 33, 521-532. https://doi.org/10.1016/j.foodpol.2008.04.005

Hossain, M., \& Bayes, A. (2009). Rural economy and livelihoods: Insights from Bangladesh. Dhaka, Bangladesh: AH Development Publishing House.

Khera, R. (2011a). Trends in Diversion of Grain from Public Distribution System. Economic \& Political Weekly (May 21, 2011, pp. 106-114).

Kumar, S. M., \& Sharma, A. N. (2013). Food security in India: performance, challenges and policies. Oxfam India Working Paper Series 08. New Delhi.

Narayanan, S. (2014). The National Food Security Act vis-à-vis the WTO Agreement on Agriculture. Economic \& Political Weekly (February 14, 2014, pp. 40-46).

Quisumbing, A. R., et al. (2013). Closing the Gender Asset Gap: Learning from value chain development in Asia and Africa.

Schanbacher, W. D. (2010). The Politics of Food: The Global Conflict between Food Security and Food Sovereignty. Santa Barbara, CA: Praeger.

Spieldoch, A. (2007). A row to hoe: The gender impact of trade liberalization on our food system, agricultural markets and women's human rights. Geneva, CH: Friedrich-EbertStiftun.

\section{Copyrights}

Copyright for this article is retained by the author(s), with first publication rights granted to the journal.

This is an open-access article distributed under the terms and conditions of the Creative Commons Attribution license (http://creativecommons.org/licenses/by/4.0/). 